\title{
PENGEMBANGAN DESAIN SENI KERAJINAN TATAH SUNGGING KULIT PUCUNG IMOGIRI BANTUL YOGYAKARTA
}

\author{
Aruman dan Toyyibah Kusumawati *)
}

\begin{abstract}
ABSTRACK
One of the central handicraft center of leather sungging in Yogyakarta is in the area of Pucung Karangasem Wukirsari Imogiri Bantul. Dusun pucung karangasem, is a village known for its leather craft. One of the famous handicraft products in the world is wayang kulit. But not only that, besides wayang, other handicraft products coming from leather can be lampshade, bookmark, tissue box, candle holder, fan, keychain, wall decoration, and others.

In running the craft business, the craftsmen joined in groups, including the group "Bimo Sukses" and "Srikandi". Each group consists of 15 to 20 craftsmen. Among them there is a focus on working on inlay, sunggingan, materials, and marketing. For the development of the design they usually develop their own order and there is mentoring design through coaching programs from campus ISI yogyakarta, one of the program is Science and Technology for Society.

For the sake of continuity and development of this leather craft business, paran crafters cooperate with the traders and lovers of shadow puppets inside and outside the country. Innovation continues to follow the developments and demands of consumers.
\end{abstract}

Keywords: design, craft, leather, Yogyakarta.

\section{ABSTRAKSI}

Salah satu daerah sentra kerajinan tatah sungging kulit di Yogyakarta adalah di daerah Pucung Karangasem Wukirsari Imogiri Bantul. Dusun pucung karangasem, merupakan desa yang dikenal akan kerajinan kulitnya. Salah satu produk kerajinan yang terkenal didana adalah wayang kulit. Namun tidak hanya itu, selain wayang, produk kerajinan lainnya yang berasal dari kulit dapat berupa kap lampu, pembatas buku, tempat tisu, tempat lilin, kipas, gantungan kunci, hiasan dinding, dan lainnya.

Dalam menjalankan usaha kerajinannya, para perajin tergabung dalam kelompokkelompok, diantaranya kelompok "Bimo Sukses" dan "Srikandi". Masing-masing kelompok terdiri dari 15 sampai 20 anggota perajin. Diantara mereka ada yang fokus mengerjakan tatahan, sunggingan, material, dan marketing. Untuk pengembangan desain mereka biasanya mengembangkan sendiri sesuai pesanan dan ada pendampingan desain melalui programprogram pembinaan dari kampus ISI yogyakarta, salah satu programnya adalah Iptek bagi Masyarakat.

\footnotetext{
* Aruman (aruman_ssn@yahoo.com), Toyyibah Kusumawati Pengajar di Jurusan Kriya Fakultas Seni Rupa Institut Seni Indonesia Yogyakarta
} 
Demi kelangsungan dan perkembangan usaha kerajinan kulit ini, paran perajin melakukan kerjasama dengan para ppedagang dan pecinta wayang kulit didalam dan luar negeri. Inovasi terus dilakukan mengikuti perkembangan dan tuntutan konsumen.

Kata kunci: desain, kerajinan, kulit, Yogyakarta.

\section{PENDAHULUAN}

Kerajinan tatah sungging merupakan kerajinan yang terbuat dari bahan kulit mentah atau kulit perkamen, yang diproses dengan cara ditatah atau dipahat kemudian disungging atau diwarnai dengan teknik gradasi. Produk dari kerajinan tatah sungging ini diantaranya yang paling terkenal adalah wayang kulit. Di Yogyakarta dikenal ada beberapa daerah sentra industri kerajinan tatah sungging kulit, salah satu diantaranya adalah di daerah Pucung Karangasem Wukirsari Imogiri Bantul. Daerah ini terletak di selatan kota Yogyakarta yaitu berjarak kurang lebih $23 \mathrm{~km}$. tepatnya berada di daerah pegunungan Imogiri, dimana makam raja Mataram Yogyakarta berada. Di daerah Wukirsari Imogiri ini selain terdapat sentra industri kerajinan tatah sungging, juga terdapat sentra industri

batik.

Kerajinan tatah sungging kulit sudah lama berkembang di daerah ini, yaitu sejak sekitar tahun 1917 an, dan terus berlangsung hingga sampai sekarang. $\mathrm{Di}$ daerah ini sekarang terdapat sekitar 963 orang pengrajin yang cukup aktif memproduksi kerajinan kulit. Mereka mendapatkan keahlian membuat kerajinan kulit secara turun temurun dari warisan nenek moyang, dan sebagian besar dari mereka menjadikan profesi pengrajin tatah sungging ini sebagai mata pencaharian utama.

Produk kerajinan kulit yang terkenal di Pucung ini adalah wayang, sehingga daerah ini dikenal sebagai sentra kerajinan wayang kulit. Berbagai jenis wayang kulit dengan ukuran dan kualitas yang beragam diproduksi oleh para pengrajin di daerah ini. Diantaranya adalah wayang pakem yang digunakan oleh para dalang dalam pertunjukan wayang, wayang untuk hiasan dan wayang mini untuk souvenir. Selain itu ada juga berbagai macam produk lainnya yang sebagian besar bernuansa wayang, diantaranya berupa kap lampu, hiasan dinding, kipas, penyekat buku, hiasan gantung (maskot), penyekat ruangan, busana wayang, dan lain-lain. Bahan yang digunakan untuk produk tersebut berupa kulit mentah dari kulit sapi, kerbau, \& kambing untuk produk yang berkualitas bagus. Sedangkan untuk produk yang berkualitas rendah biasa menggunakan kulit split yang berasal dari pabrik pengolahan kulit.

Pemasaran produk dari Pucung ini sebagian besar masih dipasarkan di pasar lokal, diantaranya di Yogyakarta, Solo, Semarang, Bandung, Bali, Jakarta dan lain-lain. Beberapa pengrajin ada juga yang sudah mampu memasarkan produk ke luar negeri diantaranya ke Suriname, Italia, Kanada, dan Thailand. Konsumen dari produk kerajinan tatah sungging 
kulit ini adalah masyarakat umun, namun untuk produk wayang kulit sebagian konsumennya adalah para dalang dan para pecinta wayang kulit.

Para pengrajin di Pucung ini ada yang memasarkan produknya secara langsung di showroomnya sendiri, dan ada juga yang melalui tengkulak ataupun pengepul/pengrajin yang lebih besar untuk dipasarkan lagi. Untuk memperluas pasar, diantara mereka ada yang sudah memasarkan produknya secara online. Sebagian dari pengrajin tersebut ada yang mempunyai website sendiri, ada yang secara kelompok, dan ada juga yang bergabung dalam pemasaran secara online yang dikelola oleh Dinas Perindustrian Perdagangan Koperasi dan UKM DIY.

Para pengrajin di Pucung ini membentuk kelompok-kelompok pengrajin. Tujuan dibentuknya kelompok ini adalah sebagai ajang untuk berdiskusi antar anggota kelompok jika ada suatu masalah yang berkaitan dengan usaha kerajinan dan pengembangannya. Selain itu dengan adanya kelompok-kelompok ini juga mempermudah koordinasi jika ada kegiatan, baik itu kegiatan/program intern kelompok maupun kegiatan/program yang berasal dari luar, misalnya programprogam dari pemerintah yang berupa pembinaan, penyuluhan, pelatihan, pendampingan, bantuan dana dan lain sebagainya.

\section{METODE}

Seperti diketahui bahwa sejak tahun 2009, setelah batik diakui sebagai world heritage oleh UNESCO, maka keberadaan industri batik di Indonesia terus mengalami perkembangan yang pesat hingga sampai sekarang. Dengan adanya perkembangan batik tersebut, maka inovasi untuk mengembangkan produk kulit yang bernuansa batik perlu dilakukan, yaitu dengan cara menerapkan motif batik pada produk kulit, dengan harapan agar nantinya produk kulit ini dapat berkembang seiring dengan perkembangan industri batik. Namun walaupun demikian ciri khas gambar wayang tetap dipertahankan, dengan cara menggabungkannya dengan motif batik, Pengembangan desain produk dengan mengaplikasikan ornamen/hiasan modern atau bebas.

Selain menerapkan motif batik pada kerajinan kulit, dalam program ini juga menerapkan hiasan/ornamen modern misalnya gambar bunga, gambar binatang, gambar bentuk-bentuk geometris dan lainlain. Rencananya hiasan atau ornamen modern ini ada yang diterapkan secara mandiri, ada juga yang digabungkan dengan gambar wayang. Pengembangan teknik pewarnaan dengan airbruh dan sablon.

Selama ini proses pembuatan kerajinan tatah sungging dikerjakan secara manual, dari mulai proses menatah sampai proses mewarnai (menyungging). Alat-alat yang digunakannya pun cukup sederhana yaitu berupa: tatah, palu, landasan dari kayu, batu asah, kuas dan tempat warna. Sehingga dengan proses ini memerlukan waktu lama dalam memproduksi kerajinan dan kualitas dari produknya pun tidak bisa konsisten. Untuk itulah perlu diperkenalkan teknik pewarnaan dengan airbrush dan sablon, yang diharapkan dapat mempercepat proses pewarnaan 
dan kualitas dari produknya pun menjadi lebih konsisten. Teknik pewarnaan ini digunakan untuk mewujudkan hiasan motif batik dan hiasan/ornamen modern, yang juga akan digabungkan dengan gambar wayang.

Pelatihan yang dilaksanakan meliputi pelatihan pengembangan desain produk dan pelatihan pembuatan produk kerajinan kulit dengan teknik pewarnaan airbrush dan sablon. Pelatihan dilakukan dengan metode ceramah, diskusi, dan praktek. Ceramah dilakukan untuk menyampaikan materi-materi yang bersifat teoritik, sedangkan praktek dilakukan dalam rangka untuk pembuatan desain dan pembuatan produk kerajinan kulit dengan teknik pewarnaan airbrush dan sablon. Dalam praktek ini tim juga memberi contoh kepada peserta. Selain itu dalam pelatihan ini juga diadakan diskusi agar para peserta dapat berdialog secara langsung dengan pelatih. Selanjutnya yang dimaksudkan dengan pembinaan disini adalah pembinaan manajemen, yang meliputi manajemen produksi, keuangan dan pemasaran. Pembinaan dilakukan dengan metode ceramah dan diskusi.

Dalam kegiatan pelatihan dan pembinaan ini, mitra berpartisipasi aktif sebagai peserta yang harus mengikuti seluruh kegiatan yang sudah direncanakan. Mitra aktif mengikuti ceramah dengan materi yang bersifat teori, dan juga aktif mengikuti praktek pembuatan desain maupun pembuatan produk.

\section{HASIL DAN PEMBAHASAN}

Pengembangan kerajinan kulit perkmen yang dilakukan dalam program $\mathrm{I}_{\mathrm{b}} \mathrm{M}$ ini diantaranya dengan cara menerapkan motif batik. Selain itu pengembangan juga dilakukan dalam proses pewarnaannya, yaitu dengan menerapkan teknik pewarnaan sablon dan airbrush. Dengan demikian proses pembuatan produk kerajinan kulit menjadi berbeda dengan proses pembuatan yang sudah lazim dikerjakan oleh para pengrajin. Adapun mengenai tahapan proses pembuatan produk kerajinan kulit secara rinci akan dijelaskan sebagai berikut.

$$
\text { Kegiatan dimulai dengan }
$$

mengadakan diskusi tim pelaksana program IbM. Dalam diskusi tersebut dibahas tentang hal- hal sebagai berikut: jadwal kegiatan, rencana kerja, dan hal-hal lainnya yang berkaitan dengan pelaksanaan program lbM.

$$
\text { Kegiatan selanjutnya adalah }
$$
konfirmasi dengan mitra, khususnya pada para ketua dan atau pengurus kelompok pengrajin tatah sungging kulit di daerah Pucung Karangasem Wukirsari Imogiri Bantul. Pada saat konfirmasi ini sekaligus membahas tentang jadwal pertemuan untuk kegiatan selanjutnya.

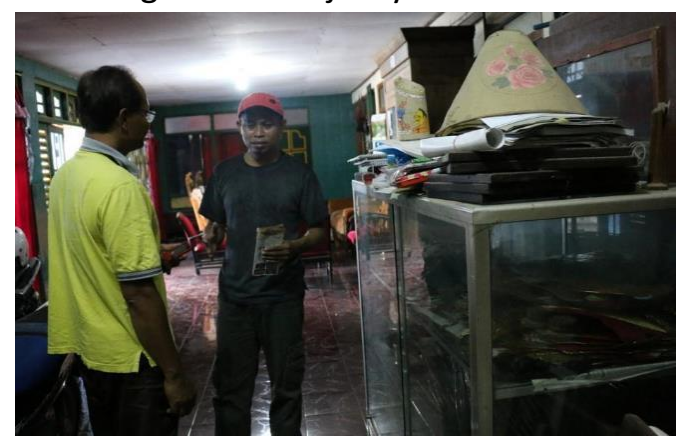

Gambar 1. Konfirmasi dengan mitra

Selain itu tim pelaksana IbM juga melakukan kegiatan persiapan konsep desain. Tim IbM membuat desain kerajinan tatah sungging kulit, yang nantinya akan disosialisasikan dan sekaligus dijadikan sebagai contoh pada saat pelatihan. Kegiatan lainnya adalah 
persiapan bahan dan alat yang diperlukan dalam pelatihan dan pembinaan. Bahan dan alat yang harus dipersiapkan/dibeli diantaranya meliputi: ATK; bermacam-macam bahan dan alat yang akan digunakan dalam proses membuat desain; kulit perkamen; bahan dan alat yang akan digunakan dalam proses membuat prototipe produk kerajinan tatah sungging kulit, kompresor dan spray gun.

Dalam tahap persiapan ini tim IbM juga mencari bahan referensi tentang gambar motif batik yang nantinya akan digandakan dan diberikan kepada para pengrajin.

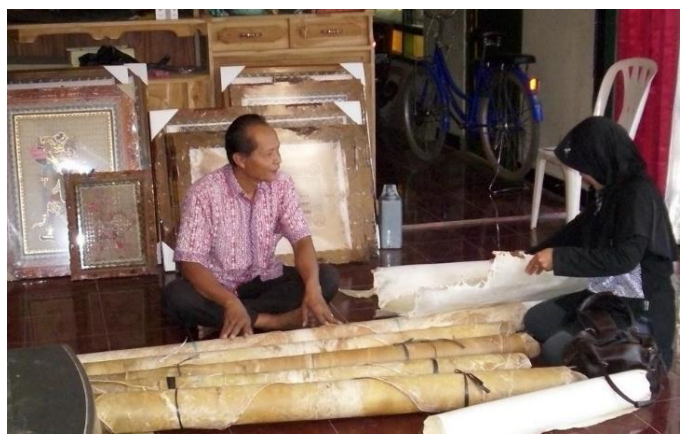

Gambar 2. Kulit kerbau

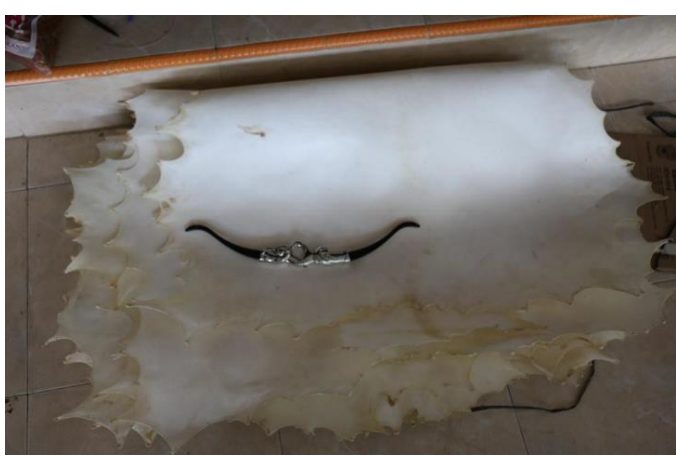

Gambar 3. Kulit kambing

Kegiatan sosialisasi dimaksudkan untuk memperkenalkan program IbM kepada pengrajin, menyampaikan rencana kegiatan yang akan dilakukan, dan mendiskusikan jadwal kegiatan.
Kegiatan sosialisasi ini diikuti oleh ketua kelompok pengrajin beserta dengan pengurus kelompok, dan beberapa anggota kelompok pengrajin.

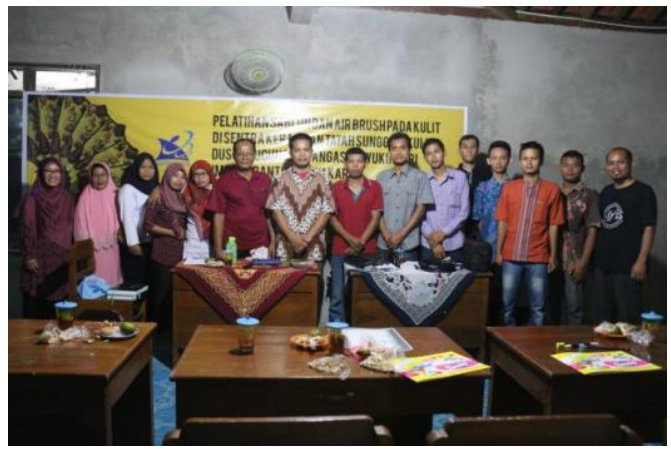

Gambar 4. Sosialisasi dan diskusi program IbM

\section{Pelatihan Pengembangan Desain Produk}

Kegiatan pelatihan ini dikuti oleh ketua kelompok beserta dengan pengurus kelompok pengrajin, dan anggota kelompok pengrajin. Kegiatan pelatihan ini meliputi teori dan praktek. Kegiatan diawali dengan penyampaian teori tentang: desain, syarat-syarat desain, cara membuat desain, dan pengenalan trend terbaru produk kerajinan. Selain itu juga pengenalan tentang motif batik dan ornamen/hiasan modern atau bebas.

Setelah penyampaian terori tersebut selesai, dilanjutkan dengan praktek membuat desain kerajinan tatah sungging kulit. Pada saat berlangsungnya kegiatan pelatihan ini para peserta diberi fasilitas, seperti: alat tulis, bahan dan alat untuk membuat desain, serta bahan referensi berupa gambar motif yang dapat digunakan sebagai acuan dalam membuat desain hiasan pada produk kerajinan tatah sungging kulit.

Kompresor, spray gun, dan peralatan sablon merupakan peralatan yang akan digunakan dalam proses 
pewarnaan kerajinan tatah sungging kulit. Dalam program IbM ini akan diperkenalkan teknik pewarnaan dengan airbrush dengan menggunakan peralatan kompresor dan spray gun, serta teknik pewarnaan sablon. Dengan teknik pewarnaan airbrush dan sablon tersebut diharapkan akan dapat mempercepat proses pewarnaan produk kerajinan tatah sungging kulit. Selain itu kualitas dari produk juga akan menjadi lebih konsisten.

\section{Pembuatan Desain}

Produk kerajinan kulit yang dikembangkan diantaranya berupa kap lampu, hiasan gantung, tempat lilin, kipas, pembatas buku, hiasan dinding dan vas bunga. Bentuk dari kerajinan kulit dibuat dengan cara mengembangkan dari bentuk kerajinan yang sdh ada. Selanjutnya kerajinan tersebut diberi hiasan motif batik. Dalam penerapannya motif batik yang sudah ada dikembangkan bentuknya dan disesuaikan dengan produk kulit. Selain itu ada yang dikombinasikan dengan motif tatahan yang biasa di terapkan pada kerajinan kulit, dan juga gambar wayang. Langkah awal yang dilakukan dalam proses pembuatan desain adalah membuat sketsa, kemudian dilanjutkan dengan penyempurnaan sketsa, sehingga menjadi gambar desain. Untuk produk hiasan gantung, kipas, dan pembatas buku, desainnya dibuat dengan ukuran skala 1:1, hal ini disebabkan karena produk tersebut ukurannya kecil.

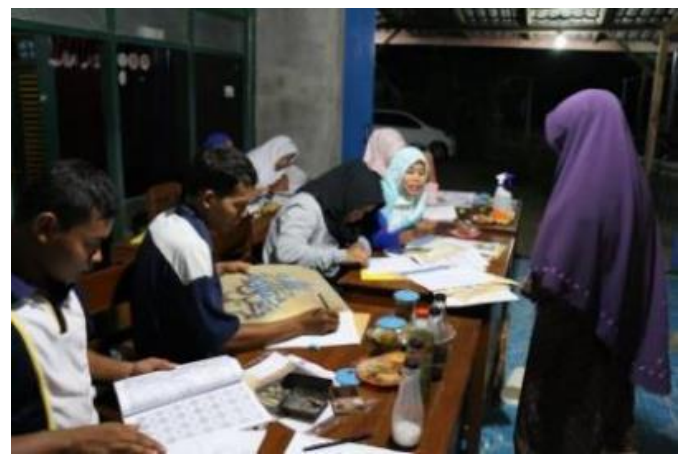

Gambar 1. Pelatihan Desain Kerajinan Kulit

Hasil Pelatihan Desain:

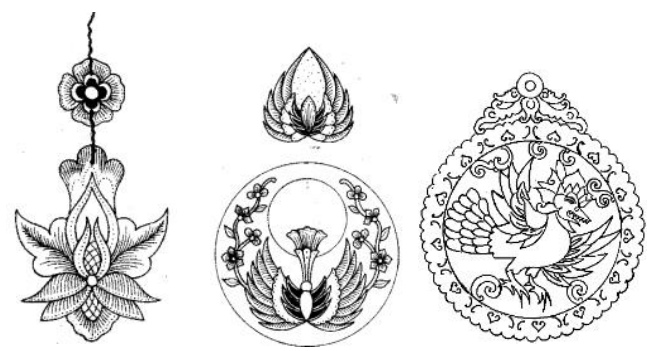

Gambar 2. Desain Gantungan hiasan Mobil
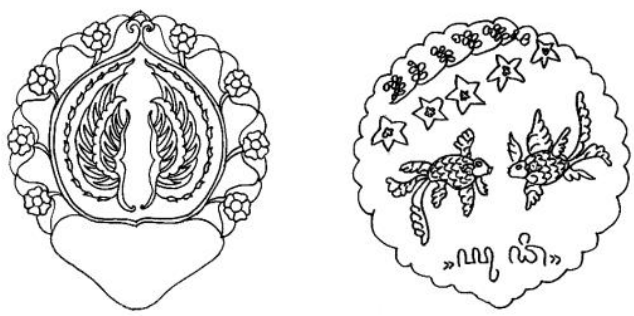

Gambar 3. Desain Kipas
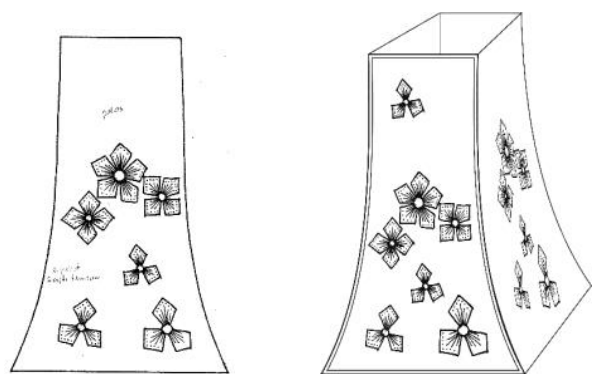

Gambar 4. Desain Vas Bunga 


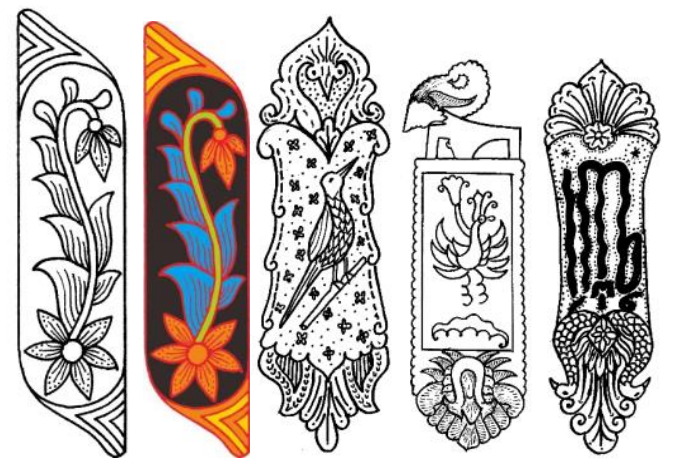

Gambar 5. Desain Pembatas buku

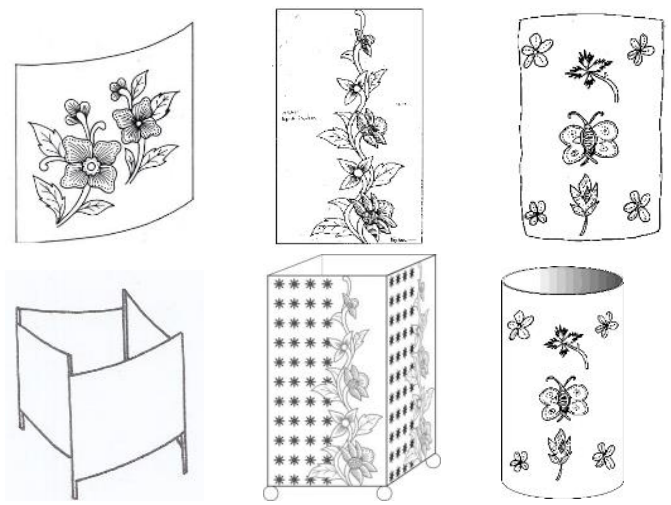

Gambar 6. Desain tempat lilin dan kap lampu

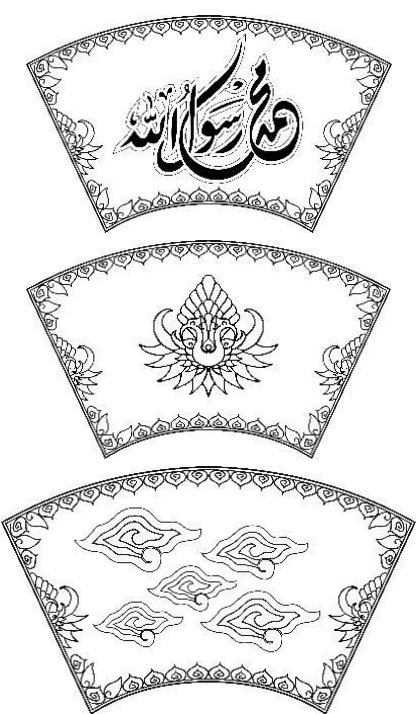

Gambar 7. Desain tempat kap lampu dinding
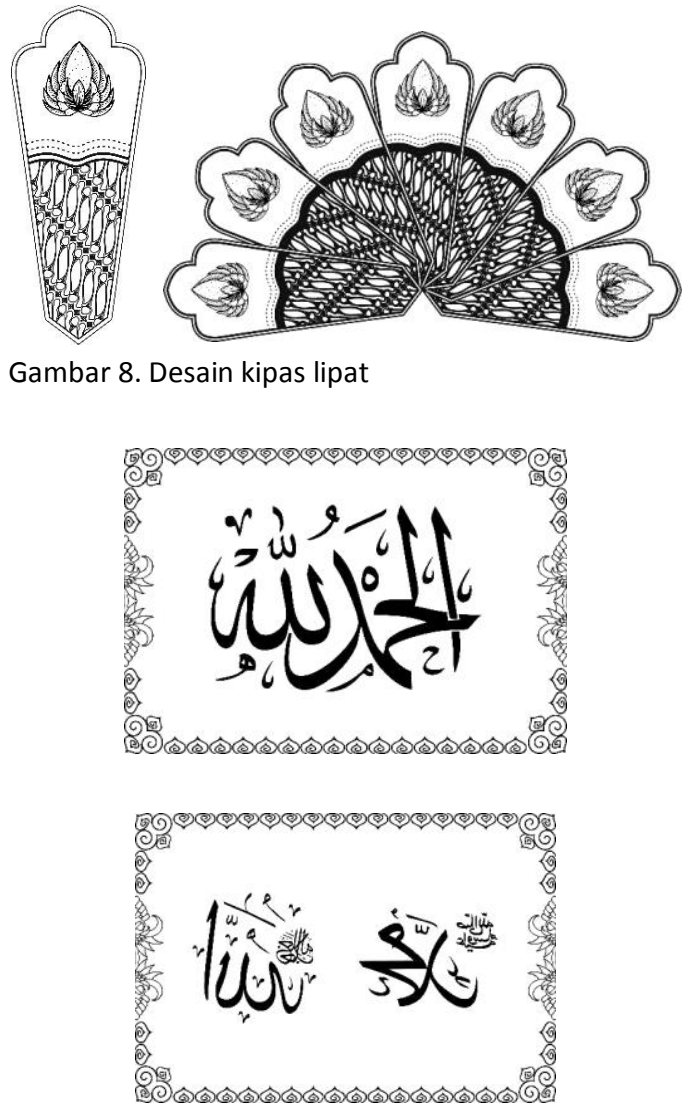

Gambar 9. Desain hiasan dinding Kaligrafi
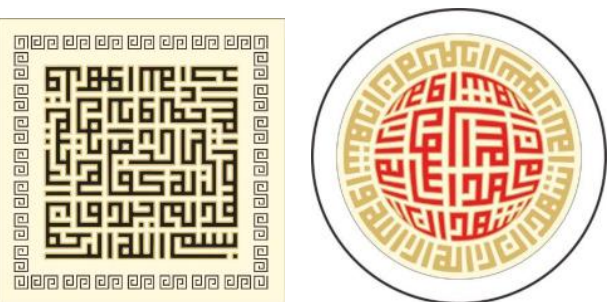

Gambar 10. Desain hiasan dinding Kaligrafi

\section{Pembuatan Pola}

Pola dibuat berdasarkan gambar desain, dengan ukuran skala 1:1, di atas kertas manila dan atau kertas HVS. Untuk produk hiasan gantung, kipas, dan pembatas buku, tidak perlu dibuatkan polanya, karena desainnya sudah dibuat dengan skala $1: 1$.

Untuk pola dengan tek nik sablon di desain terlebih dahulu, kemudian di scan. Kemudian gambar di olah di program 
potohsop dan corel, ukuran disesuaikan dengan ukuran 1:1. Setelah itu di print dengan print laser, untuk mendapatkan hasil yang rapi dan detail untuk proses afdruk pada screen.

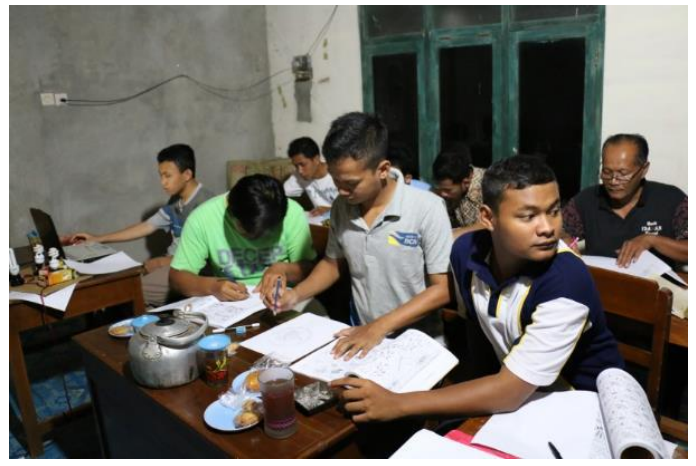

Gambar 11. Suasana pelatihan desain kerajinan kulit

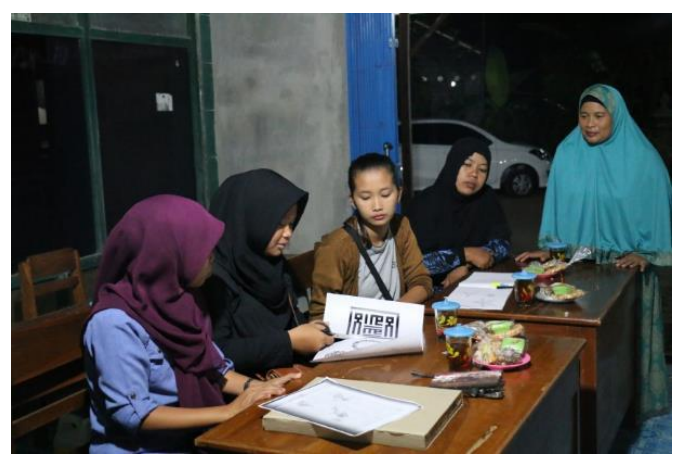

Gambar 12. Suasana pelatihan membuat pola kerajinan kulit

\section{Pemotongan Bahan}

Bahan utama yang digunakan dalam pembuatan produk kulit ini adalah kulit perkamen kerbau dan kulit kambing. Pemotongan bahan dilakukan dengan menggunakan gunting maupun cutter. Kulit dipotong berdasarkan pola yang sudah dibuat.

\section{Proses Pewarnaan dengan teknik sablon dan airbrush}

Pada prinsipnya proses penyablonan pada kulit sama denga proses penyablonan pada kain atau kertas. Bahan yang dipakai dapat dari bahan berbasis air dan minyak.

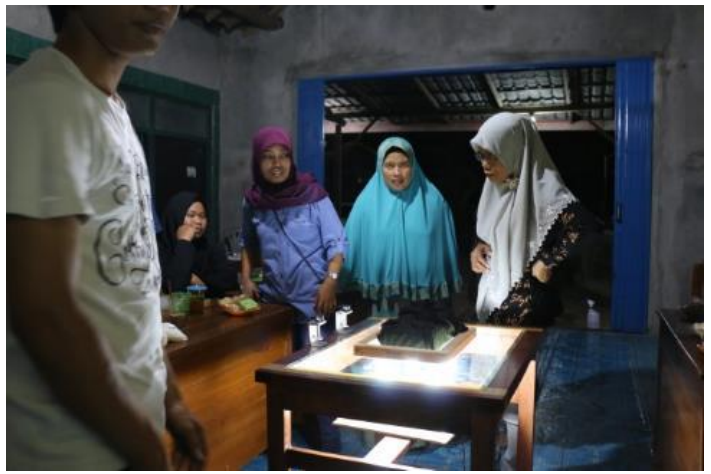

Gambar 13. Proses afdruk pada screen

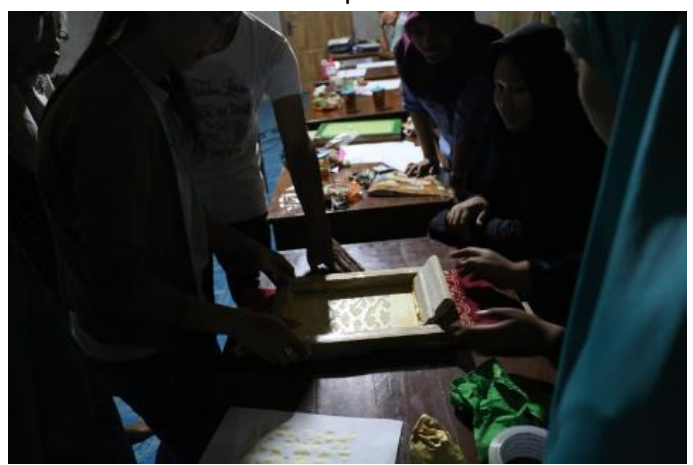

Gambar 14. Proses Sablon pada kulit

\section{Contoh hasil latihan penyablonan}

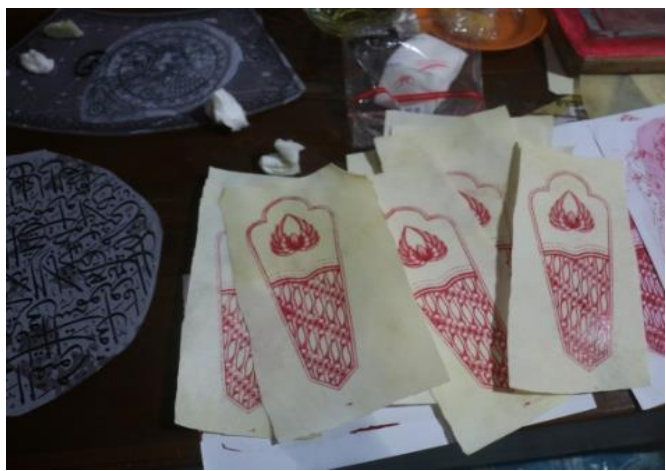

Gambar 15. Hasil Sablon pada kulit kambing

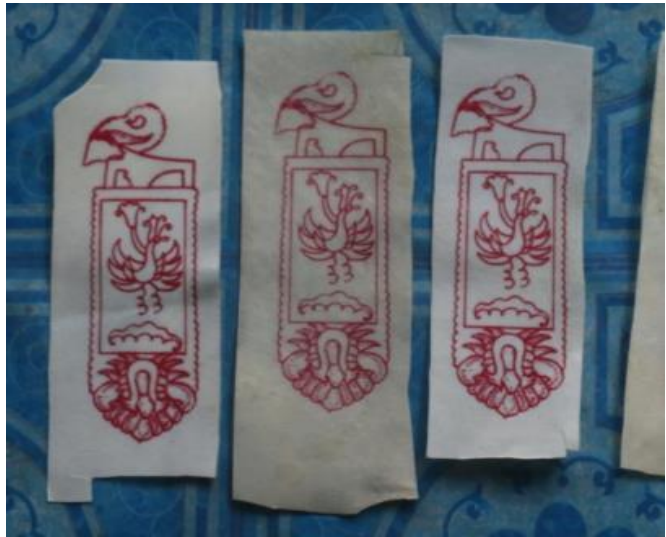

Gambar 16. Hasil pelatihan sablon kipas dan pembatas buku ada kulit kambing 


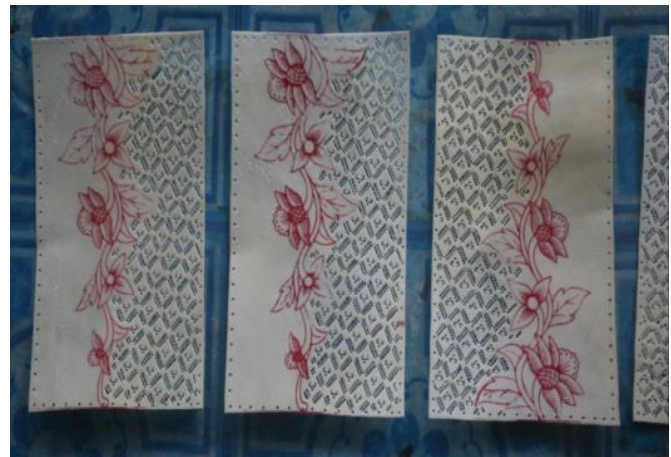

Gambar 17. Hasil pelatihan sablon kap lampu

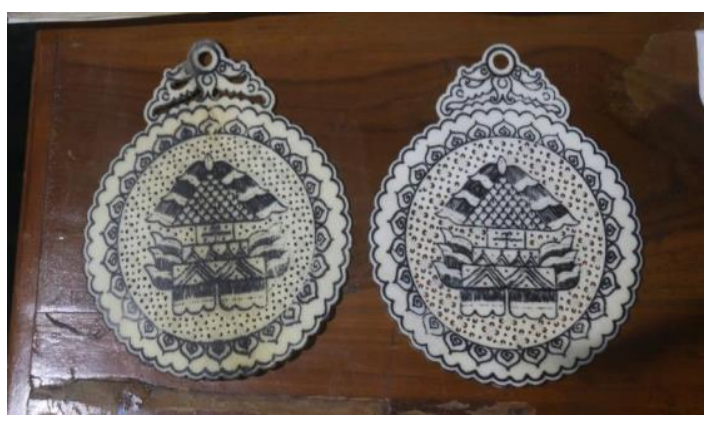

Gambar 18. Hasil pelatihan sablon hiasan gantung mobil

\section{Proses pewarnaan dengan spray}

Langkah pertama adalah membuat pola dengan cara melubangi gambar dengan cutter pada kertas stiker. Setelah itu gambar ditempelkan pada kulit, lalu disemprot dengan cat menggunakan spraygun.

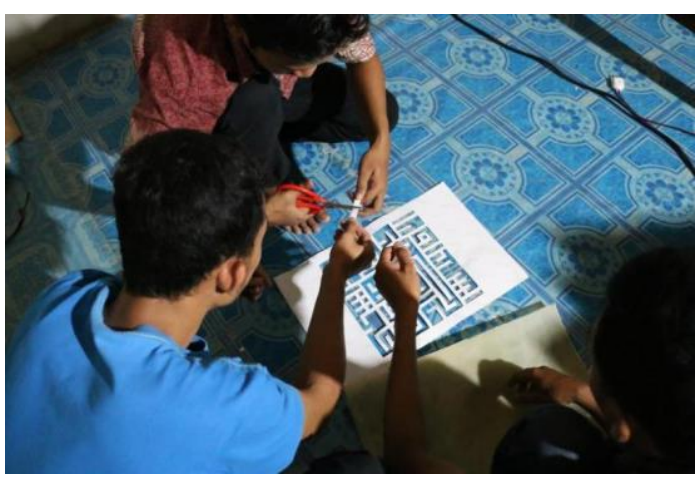

Gambar 19. Proses membuat pola untuk teknik spray

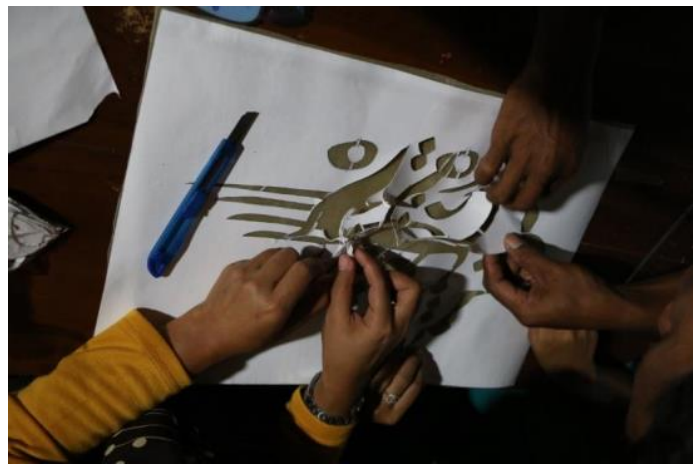

Gambar 20. Proses menempelkan pola pada kulit perkamen
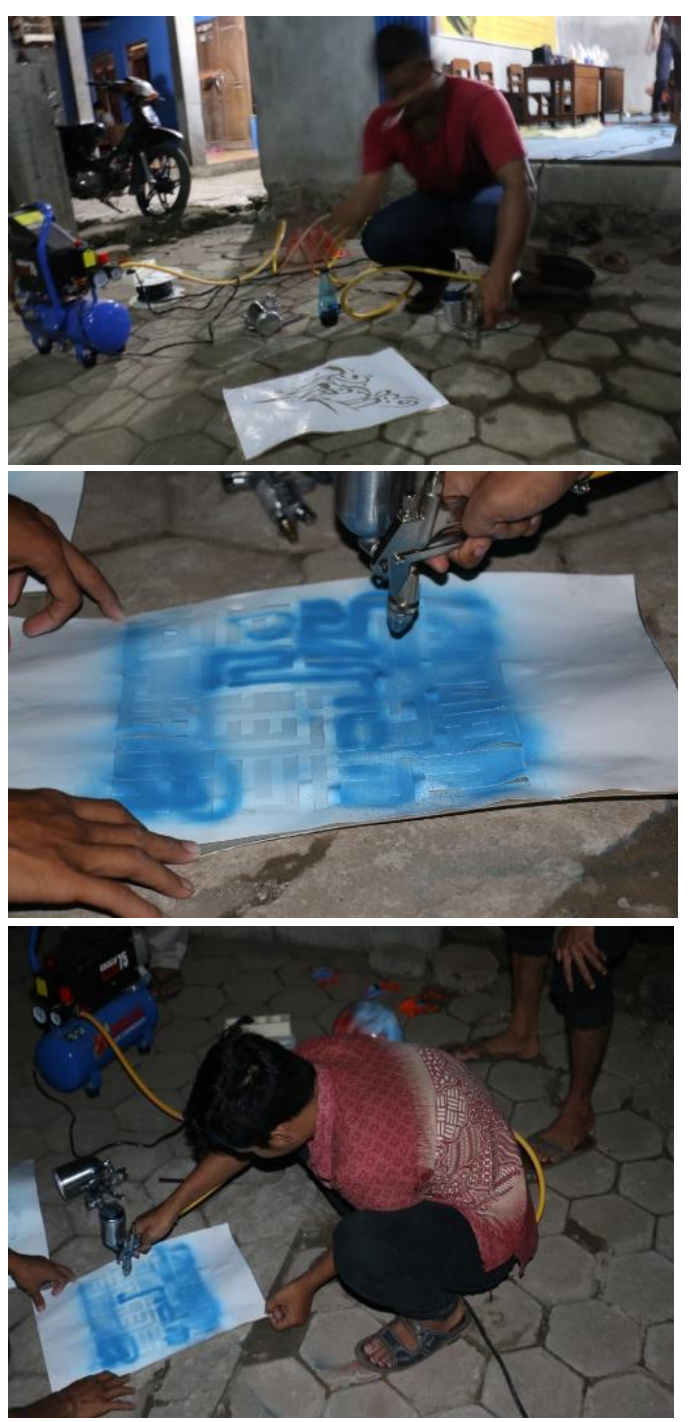

Gambar 21. Proses penyemprotan 


\section{Proses Menatah}

Setelah proses sablon ataupun airbrush selesai, selanjutnya adalah proses menatah. Sebagian produk ada yang ditatah pada bagian dasarannya dan bagian hiasan yang sudah diwarna dengan teknik sablon ataupun airbrush. Sebagian produk yang lainnya ada yang hanya ditatah pada bagian dasarannya atau pada bagian motif tatahan saja, dan bagian hiasan dibiarkan hanya berwarna tanpa dipahat.

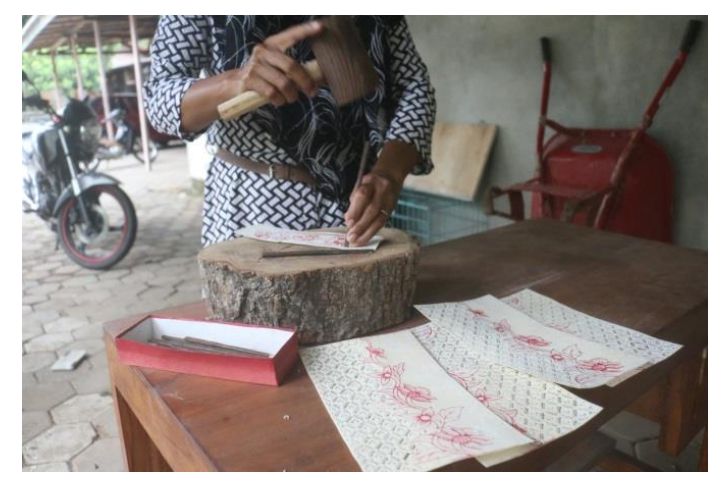

Gambar 22. Proses pemahatan setelah di sablon

\section{Proses Pewarnaan}

Pada bagian hiasan yang sudah diwarna dengan teknik sablon ataupun airbrush, selanjutnya diberi warna transparan, sehingga hiasan motif batik tampak lebih indah. Bahan warna yang digunakan untuk efek transparan adalah cat sandi yang dicampur dengan lem kayu dan air.

\section{Proses merangkai}

Kulit yang sudah diwarna tersebut selanjutnya dirangkai dengan kerangkanya. Untuk produk kap lampu, tempat lilin, dan vas bunga kerangkanya terbuat dari besi. Sedangkan untuk produk kipas kerangkanya dari tanduk. Untuk hiasan dinding cukup dipasang pada bingkai yang terbuat dari kayu. Bagian kulit tersebut dirangkai dengan menggunakan benang nilon.
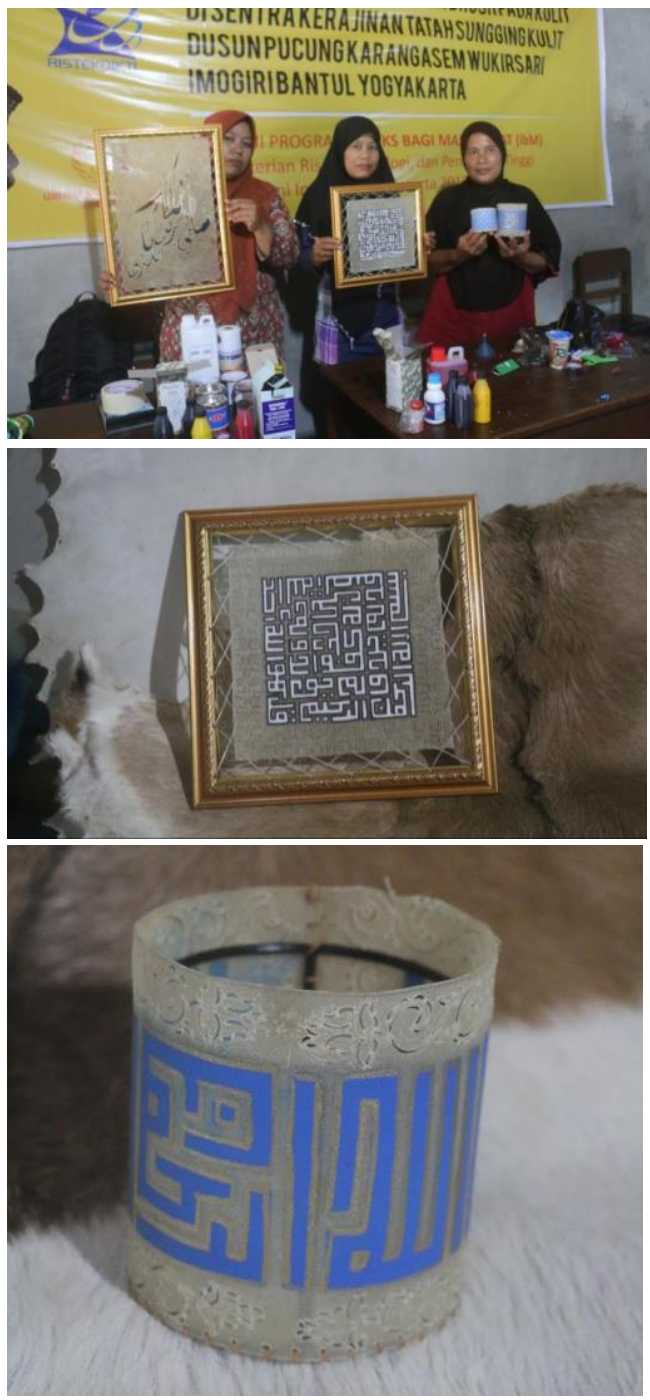

Gambar 23. Hasil Karya kaligrafi

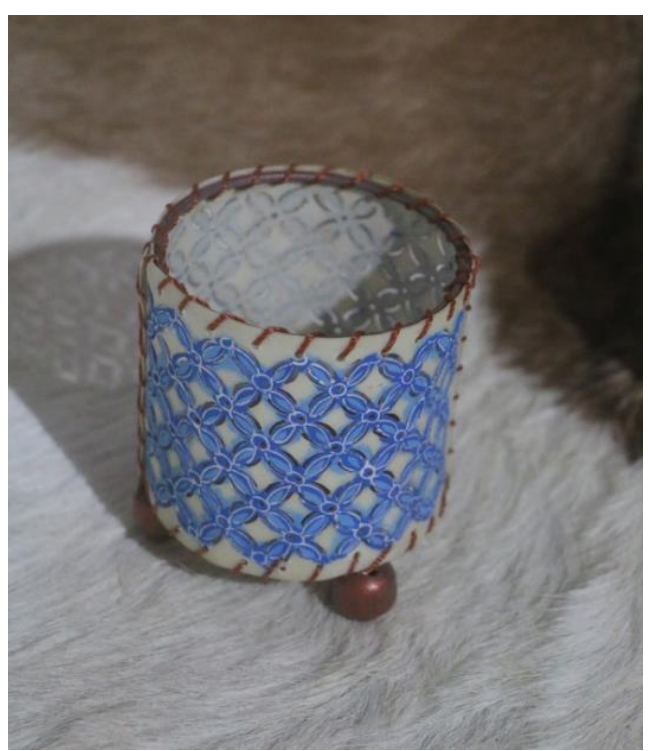

Gambar 23. Hasil Karya kap lampu 


\section{PENUTUP}

Iptek bagi Masyarakat merupakan program pengabdian kepada masyarakat yang pelaksanaannya hanya mono tahun, tepatnya hanya berlangsung kira-kira tujuh bulan. Kegiatan yang telah direncakanan dalam program IbM ini belum semuanya dapat dilaksanakan sesuai dengan rencana semula. Hal ini disebabkan karena adanya kendala yang datang dari para pengrajin, yaitu dalam waktu yang bersamaan ini pengrajin sedang sibuk mempersiapkan produk untuk pameran, sehingga mereka tidak punya waktu yang banyak untuk mengikuti kegiatan

Adapun kegiatan yang telah dilaksanakan diantaranya meliputi: kegiatan persiapan; sosialisasi program I Iptek bagi Masyarakat kepada pengrajin; pelatihan pengembangan desain produk; pemberian alat yang meliputi: kompresor, spray gun, dan peralatan sablon kepada mitra.

Kegiatan selanjutnya adalah melanjutkan kegiatan pelatihan pengembangan desain produk; pelatihan pembuatan kerajinan dengan teknik pewarnaan airbrush dan sablon; serta kegiatan pembinaan manajemen.

\section{DAFTAR PUSTAKA}

Anonim,1985, Motif Batik, Balai Besar Kerajinan dan Batik, Yogyakarta. Chandra, Gregorius, 2005, Strategi dan Program Pemasaran, Andi Ofset, Yogyakarta.
Djojowidagdo, Soemitro, 1988, Kulit Kerbau Lumpur Jantan, Sifat-Sifat dan

Karakteristiknya Sebagai Bahan Wayang Kulit PURWA, UGM Yogyakarta.

Gatot P., Muhammad dan Abidin, Zainal, 2003, T-shirt Unik dengan Lukian Air brush, Kawan Pustaka, Jakarta.

Palgunadi, Bram, Desain Produk 2 : Analisis dan Konsep Desain, Penerbit ITB Bandung.

Pernawa, Surya, 1996, Desain Kerajinan Kulit, Petunjuk Pelatihan Ketrampilan Industri Kerajinan Kulit, Departemen Pendidikan dan Kebudayaan, Direktorat Jenderal Pendidikan Dasar Menengah, Direktorat Pendidikan Menengah Kejuruan

Ranjiwa, Hand's, 2005, Teknik Dasar Air Brush untuk Pemula, Kawan Pustaka, Jakarta.

Subanar, Harimurti, 2001, Manajemen Usaha Kecil, BPFE, Yogyakarta. Setiawan, Acip, 2007 Sohor jadi Modifikator Motor, Gramdeia Pustaka, Jakarta.

Sunarto dan Sagio, 2004, Wayang Kulit Gaya Yogyakarta, Bentuk dan Ceritanya, Pemerintah Propinsi DIY, Kantor Perwakilan Daerah Pripinsi DIY. 2001, Bahan Kulit untuk Seni dan Industri, Kanisius, Yogyakarta.

Susanto, Sewan, 1980, Seni Kerajinan Batik Indonesia, Balai Penelitian Batik dan 
24 ] CORAK Jurnal Seni Kriya Vol. 6 No.1, Mei-Okteber 2017

Kerajinan, Lembaga Penelitian dan

Pendidikan Industri, Departemen

Perindustrian RI. 